\title{
Oculobairdoppilata gen. nov. (Ostracoda, Bairdiidae): a new genus from the Paleocene of Tunisia
}

\author{
JIMMY VAN ITTERBEECK ${ }^{1,2}$, ABDEL-MOHSEN M. MORSI $^{3}$, DAVID J. HORNE ${ }^{4}$ \& ROBERT P. SPEIJER ${ }^{1}$ \\ ${ }^{1}$ Department of Geography and Geology, KULeuven, Redingenstraat 16, 3000 Leuven, Belgium (e-mail: jvanitterbeeck@yahoo.co.uk, \\ robert.speijer@geo.kuleuven.be) \\ ${ }^{2}$ Current address: Shell International Exploration and Production, Kesslerpark 1, 2288GS Rijswijk, The Netherlands \\ ${ }^{3}$ Geology Department, Faculty of Science, Ain Shams University, 11566 Cairo, Egypt (e-mail: ammorsi@hotmail.com) \\ ${ }^{4}$ Department of Geography, Queen Mary, University of London, Mile End Road, London E1 4NS, UK and Department of Zoology, \\ The Natural History Museum, Cromwell Road, London SW7 5BD, UK (e-mail: d.j.horne@qmul.ac.uk)
}

\begin{abstract}
A new marine ostracod genus, Oculobairdoppilata, belonging to the family Bairdiidae, is described from Paleocene deposits in Tunisia. Its main characteristic is the occurrence of an eye tubercle in the anterodorsal part of the valves. Internally, small denticles and corresponding sockets are present at the terminal parts of the dorsal edge of the right and left valves, respectively. It is the first bairdiid with an external eye structure to be described, although the existence of such a genus was predicted previously. J. Micropalaeontol. 26(2): 97-101, October 2007.
\end{abstract}

KEYWORDS: Paleocene, Tunisia, Ostracoda, Oculobairdoppilata, Tethys

\section{INTRODUCTION}

The Family Bairdiidae (Ostracoda, Podocopida) is a diverse group of marine ostracods with a fossil record stretching back to the Early Palaeozoic. All currently known bairdiid ostracods have no external eye structure (e.g. eye-tubercle, eye-spot in the valves). As most of them live in the photic zone, it is probable that many (if not all) are not blind but have an ocular system that is expressed only internally in the soft parts. Neonesidea oligodentata (Kajiyama, 1913), for example, which lives in the coastal waters of Japan has a nauplius eye like that of other podocopan ostracods, but lacks any eye-related carapace structure (Tanaka, 2005). In his review of all genera of the family Bairdiidae, Malz (1988) speculated about hypothetical, still undiscovered bairdiid ostracods including forms he named as 'Ophthalmobairdia', which would be characterized by an external eye structure (Malz, 1988, fig. 6). When Morsi \& Speijer (2003) described their new 'Bairdia' species with an anterodorsal tubercle, 'Bairdia' malzi, they were unable to determine whether or not this represented an ocular structure due to the poor preservation of their material. However, they mentioned that this species may be assigned to a new genus. In fact, 'Bairdia' specimens with similar structures have been figured by several authors before: Bairdia sp. 1 (Honigstein et al., 1991, pl. 1, fig. 2) and Bairdia ilaroensis (Bassiouni \& Luger, 1990, pl. 1, fig. 15). During a study of the ostracods in the Danian/ Selandian boundary interval of the Sidi Nasseur sections in Tunisia (Fig. 1), similar 'Bairdia' specimens with an anterodorsal tubercle and marginal denticles internally at the terminal parts of the dorsal edge in the right valve were observed and at that time identified as 'Bairdia' malzi (Van Itterbeeck et al., 2007). Closer examination revealed the anterodorsal tubercle to be an ocular structure; accordingly, here, the long-predicted (Malz, 1988) genus of bairdiid ostracods with an external eye structure is described.

The higher classification of Horne et al. (2002) is followed.

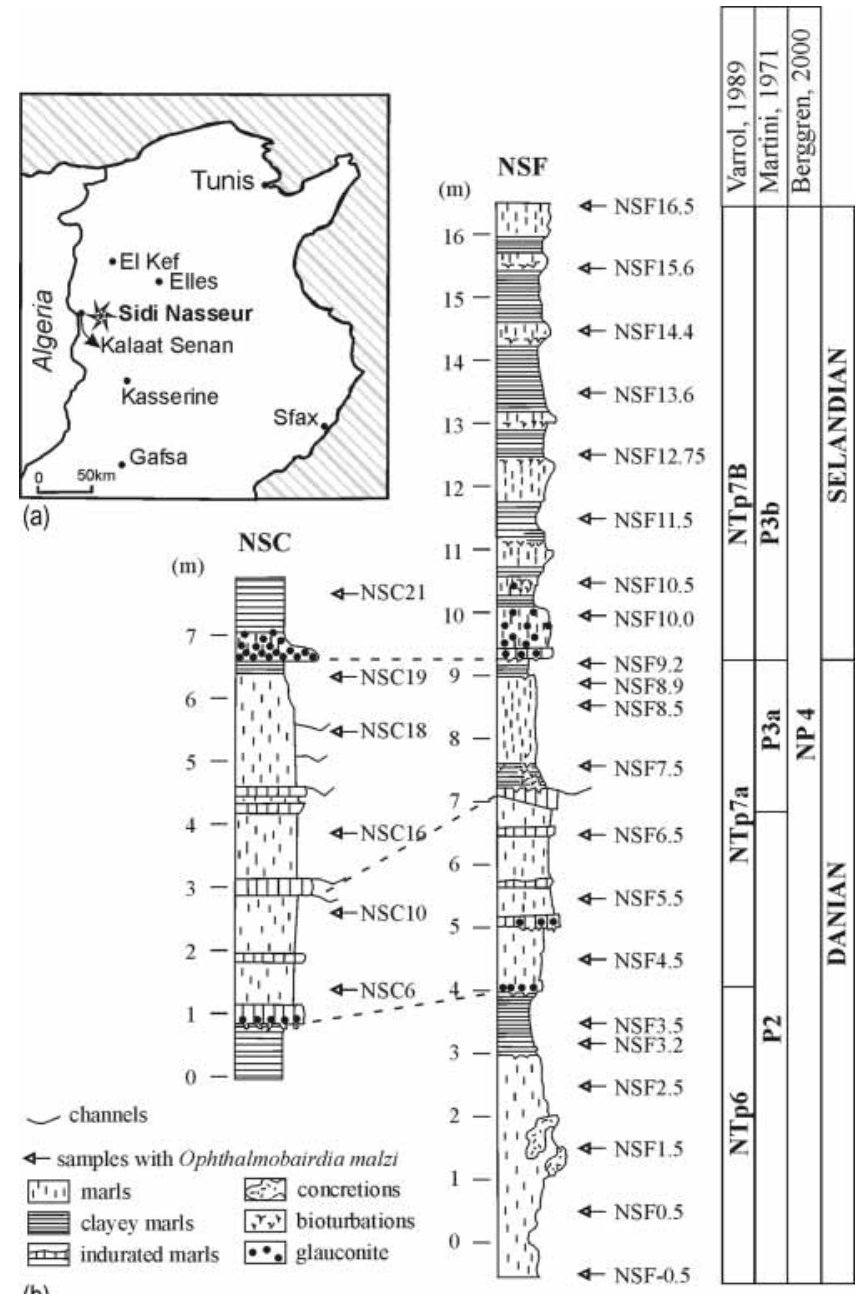

(b)

Fig. 1. (a) Location of the Sidi Nasseur sections in northern Tunisia. (b) Litho- and biostratigraphy of the Sidi Nasseur sections with calcareous nannoplankton zonations according to Martini (1971) and Varol (1989) and planktic foraminifera zonations according to Berggren et al. (2000). 


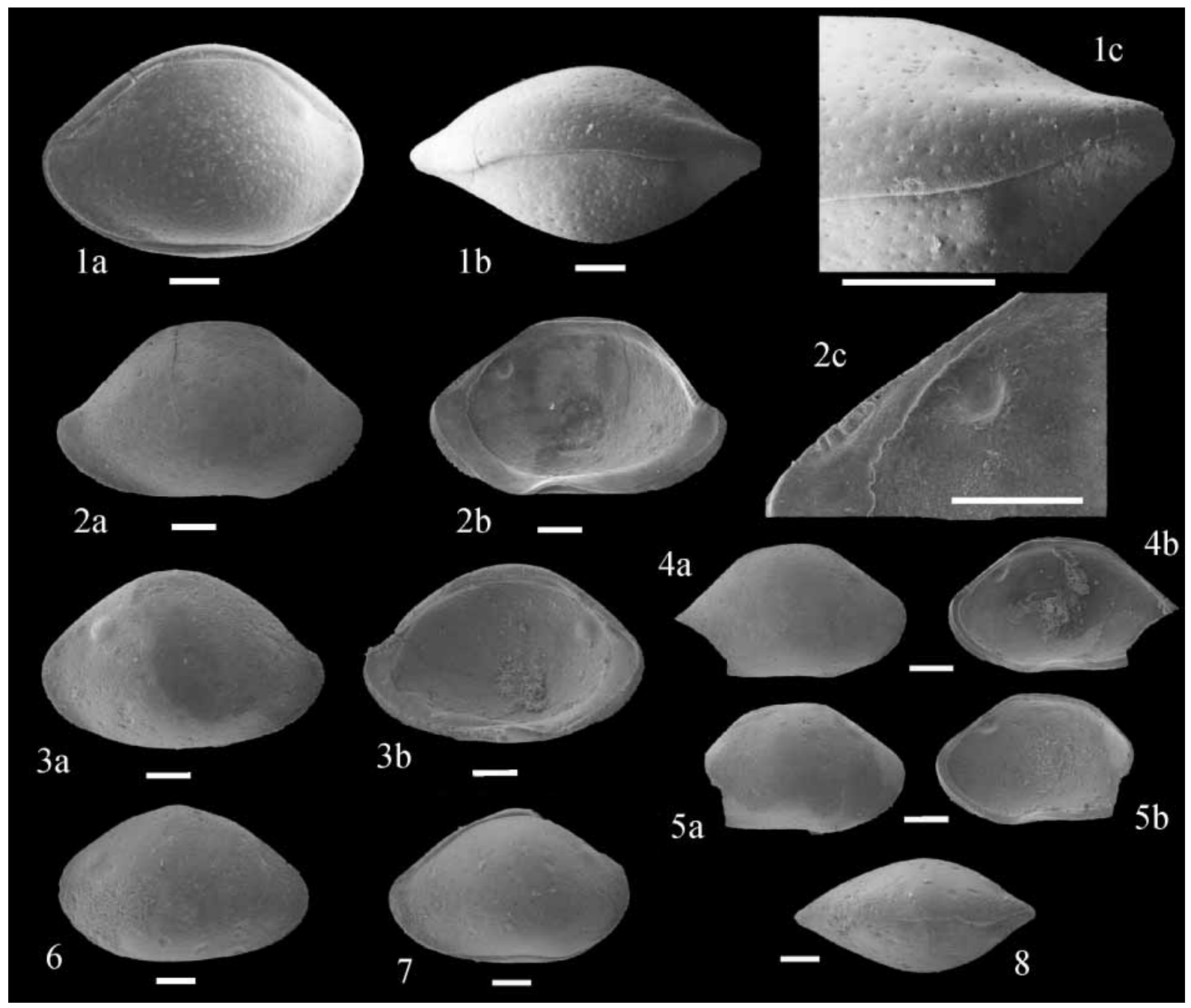

Explanation of Plate 1.

Oculobairdoppilata malzi (Morsi \& Speijer, 2003). fig. 1. From Gebel Aweina (reproduced from Morsi \& Speijer, 2003) - (a) right lateral view, (b) dorsal view, (c) detail of eye tubercle in dorsal view. figs 2-3. From the Sidi Nasseur sections: 2, right adult valve (b4596) - (a) external view, (b) internal view, (c) detail of internal eye tubercle; 3, left adult valve (b4597) - (a) external view, (b) internal view. figs 4-5. Right juvenile valve from the Sidi Nasseur sections (b4598/b4599) - (a) external view, (b) internal view. figs 6-8. Adult carapaces from the NAS section (b4600/4601/4602), Tunisia: 6, left view; 7, right view; 8 , dorsal view. Scale bar $=200 \mu \mathrm{m}$.

\section{SYSTEMATIC DESCRIPTION}

Class Ostracoda Latreille, 1802

Subclass Podocopa G. W. Müller, 1894

Order Podocopida Sars, 1866

Superfamily Bairdioidea Sars, 1888

Family Bairdiidae Sars, 1888

Genus Oculobairdoppilata gen. nov.

(P1. 1, figs 1-8; Pl. 2, fig. 1)

Type species Oculobairdoppilata malzi (Morsi \& Speijer, 2003, pl. 1, figs 7-9; pl. 2, figs 7, 10-11).

Derivation of name Prefix oculo- referring to eye, as it is the first bairdiid genus possessing an eye tubercle, plus suffix -bairdoppilata, as it has denticles internally at the terminal parts of the dorsal edge in the right valve, as described for the genus
Bairdoppilata Coryell, Sample \& Jennings, 1935. In 1988, Malz already speculated on the existence of such bairdiids with eye tubercles to which he proposed the name Ophthalmobairdia. Malz (1988, fig. 6) even gave a speculative drawing that strongly resembles the specimens here. The name suggested by Malz, Ophthalmobairdia, has not been utilized herein to avoid confusion since it is registered in the 'Index and Bibliography of Marine Ostracoda 6, Index A, Supplement 1' as nomen nudum: Ophthalmobairdia (NN) Malz, 1988 B (Kempf, 1995).

Diagnosis A genus of the family Bairdiidae characterized by the presence of a well-developed eye tubercle on the anterodorsal part of both valves. In internal view, an ocular sinus or depression is absent; on the contrary, a calcite thickening is present forming a biconvex lensoid structure. The terminal parts of the dorsal edge in the right valve develop weak small denticles; in the left valve, small sockets are complementary. 


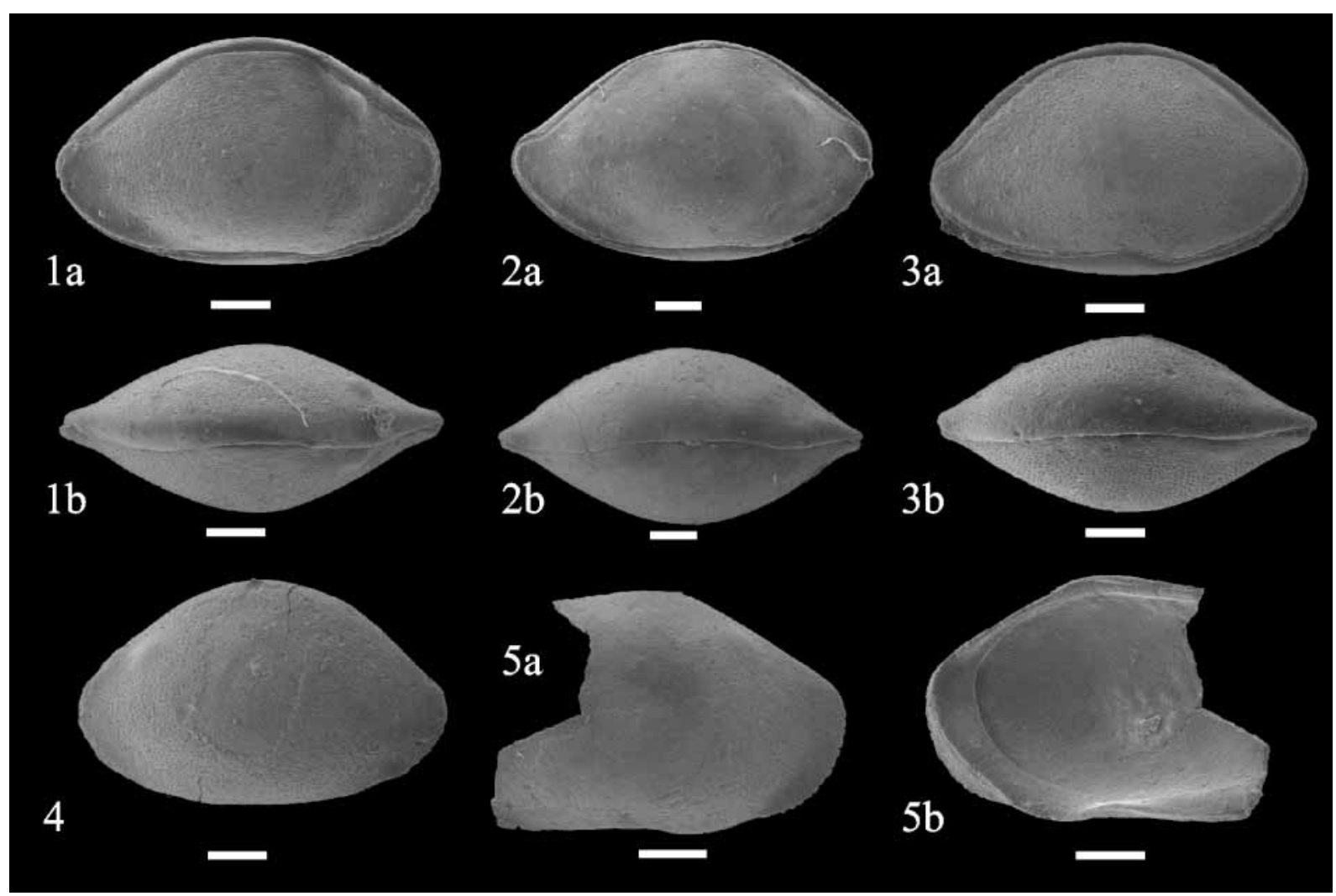

Explanation of Plate 2.

fig. 1. Oculobairdoppilata malzi (Morsi \& Speijer, 2003), adult carapace (b4603) - (a) right view, (b) dorsal view. figs 2-5. Bairdia septentrionalis (reproduced from Van Itterbeeck et al., 2007): 2-3, adult carapaces - (a) right view, (b) dorsal view; 4, left adult valve; 5, right adult valve - (a) external view, (b) internal view. Scale bar $=200 \mu \mathrm{m}$.

Description Carapace large, with a typical bairdioid outline. Left valve larger than right valve. Anterior margin broadly rounded; posterior margin narrower than anterior margin. Lateral surface smooth, sometimes displays small pits of normal pore canals. Eye tubercle developed at anterodorsal region. In dorsal view, carapace oval with tapering ends. Hinge simple, where dorsal edge of the right valve fits into groove of the left valve. Small denticles are present at the anterior and posterior marginal angles of the right valve; small sockets are complementary in the left valve. At the position equivalent to the external eye tubercle, a calcite thickening forming a biconvex lensoid structure is present. Juvenile carapaces variably display the eye tubercles at anterodorsal region of their valves (P1. 1, figs 4-5). Marginal zone well developed, widest anteriorly, with vestibule anteriorly and posteriorly. Line of concrescence parallel to outer margin. Selvage developed near outer margin. Marginal pore canals numerous, simple and straight. Normal pore canals simple. Muscle scar pattern typically bairdioid (Pl. 1, fig. 2b).
Distribution The type species for this genus, Oculobairdoppilata malzi, was described originally from the Paleocene/Eocene boundary beds in Egypt (Morsi \& Speijer, 2003). It has also been reported here from the Danian/Selandian transition beds (Van Itterbeeck et al., 2007) and also observed higher up at the Paleocene/Eocene transition in the Sidi Nasseur sections in Tunisia (Pl. 1, figs 6-8). The genus seems to have been established throughout the 'Protobuntonia numidica ostracode province' of the Southern Tethys (as defined by Luger, 2003) during the Paleocene-Eocene periods. This is especially so if one takes into account the specimens reported by Honigstein et al. (1991) from the lower and middle Eocene of Israel and those illustrated by Bassiouni \& Luger (1990) from the upper Paleocene of Southern Egypt (Table 1), although their generic status still has to be confirmed.

Discussion Although the type species was described originally from the Paleocene/Eocene of Egypt (Morsi \& Speijer, 2003), the

\begin{tabular}{llll}
\hline Locality & \multicolumn{1}{c}{ Age } & \multicolumn{1}{c}{ Environment } & Ref. \\
\hline Sidi Nasseur, Tunisia & Danian-Thanetian (P2-P5a) & Middle to outer neritic (50-175 m) & (Van Itterbeeck et al., 2007) \\
Gebel Aweina, Egypt & Thanetian-Ypresian (P5a-c) & Outer neritic (150-175 m) & (Morsi \& Speijer, 2003) \\
Qeren Sartaba, Jordan Valley, Israel & Ypresian-Lutetian (P9-P10) & Middle to outer neritic (50-150 m) & (Honigstein et al., 1991) \\
Bir Abu El-Husein, Egypt & Thanetian (P4) & Garra type, middle neritic (50-100 m) & (Bassiouni \& Luger, 1990) \\
\hline
\end{tabular}

Table 1. Occurrence of Bairdiid specimens with (potential) eye structures. 
erection of the genus Oculobairdoppilata is based on the present material of Oculobairdoppilata malzi (Morsi \& Speijer, 2003) retrieved from the Sidi Nasseur sections in Tunisia. The specimens figured in this publication are deposited at the Royal Belgian Institute for Natural Sciences (KBIN-IRSNB, collection numbers b4596-b4603).

The Egyptian material does not display the diagnostic internal features very clearly due to the poor preservation of separate valves. On the contrary, the better state of preservation of the Tunisian material enabled more detailed investigation of the internal features, which argue for the erection of the new genus and differentiate it from all the other related genera. Oculobairdoppilata can be distinguished easily from other bairdiid genera by the presence of the eye tubercle as described in the present paper. The genus Bairdoppilata (Coryell et al., 1935) resembles Oculobairdoppilata gen. nov. in having small denticles at the anterior and posterior marginal angles of the right valve but lacks, like the other bairdiids, the eye tubercles. From a biological point of view, this new genus has important implications. The eye structures described from recent bairdiids all belonged to the rather primitive eye type-1 (following the classification of Tanaka, 2005). The structures observed in Oculobairdoppilata clearly belong to a more advanced eye type. Although it is difficult to judge because no soft parts are preserved, it is the authors' opinion that the biconvex lens in Oculobairdoppilata should be classified as an eye type 4/5 (Tanaka, 2005, table 3, fig. 5). Hard-part eye structures are common and well known in some other Podocopida, e.g. Cytheroidea. Bairdiids have always been considered a very conservative group as they are recorded from the early Paleozoic to the present with very little variation in the basic morphological characters. Malz (1988) advocated a different opinion, hypothesizing about the possible variation within this group. The recognition of this new genus supports this hypothesis and clearly indicates an underestimation of the amount of variation and evolution within this group. As indicated, more bairdiid specimens with possible eye structures have been reported (Table 1). Their future revision will almost certainly shed a new light on the evolution of this group.

The development of a more complex eye structure should have an evolutionary advantage only in the photic zone. However, to date, most of the bairdiids with an external eye structure have been recovered from shelf sediments believed to be below the photic zone $(100-200 \mathrm{~m})$ based on benthic foraminiferal evidence. The successive highest occurrences of deeper-dwelling benthic foraminifera taxa, such as Anomaloides avnimelechi, $A$. abudurbensis, A. affinis, A. susanaensis, Cibicidoides pseudoacutus and Spiroplectinella dentata, in the Sidi Nasseur section indicate a general shallowing trend from deep outer neritic $(175 \mathrm{~m})$ to shallow outer neritic $(125 \mathrm{~m})$ environments (Van Itterbeeck et al., 2007). Possibly $O$. malzi also occurs in the deeper parts of the euphotic zone $(0-100 \mathrm{~m})$ (Table 1$)$.

Oculobairdoppilata malzi (Morsi \& Speijer, 2003) (Pl. 1, figs 1-8; Pl. 2, fig. 1)

2003 'Bairdia' malzi Morsi \& Speijer: 70, pl. 1, figs 7-9; pl. 2, figs 7, 10-11.

Material $>100$ carapaces and $>250$ valves.
Occurrence The present species was described originally from the Paleocene/Eocene boundary beds within the Esna Formation at Gebel Aweina, Eastern Desert, Egypt (Morsi \& Speijer, 2003) and has been reported here from the Ain Settara Marls, El Haria Formation, Sidi Nasseur sections (Danian/Selandian transition) (Van Itterbeeck et al., 2007). It has also been observed from the Paleocene/Eocene transition higher up in the same Tunisian sections (P1. 1, figs 6-8).

Remarks Oculobairdoppilata malzi, from the Eastern Desert of Egypt, was described in detail and compared with similar taxa by Morsi \& Speijer (2003), the authors of the species. Wellpreserved closed carapaces as well as open valves have been recovered from the Sidi Nasseur sections in Tunisia. They display all the external and internal features described by Morsi \& Speijer (2003). Moreover, the open valves internally exhibit a biconvex lensoid structure at the position equivalent to the external eye tubercle, small denticles at the anterior and posterior marginal angles of the right valve, and complementary small sockets in the left valve. This internal ocular structure and the terminal teeth were not mentioned in the first description of the species as they were not displayed very clearly in the Egyptian material due to poor preservation. Although not as distinct as in the adults, the juvenile carapaces recorded in the Tunisian sections also display the presence of the eye tubercles at anterodorsal region of their valves (Pl. 1, figs 4-5). Several specimens from the Sidi Nasseur sections, identified as Bairdia septentrionalis also show evidence of tubercles in the anterodorsal part of their valves (Pl. 2, figs 2-5). These tubercles are not as distinct as in Oculobairdoppilata malzi and are clearly not eye structures as there is no internal expression ( $\mathrm{Pl} .2$, fig. 5b).

\section{ACKNOWLEDGEMENTS}

The authors are greatly indebted to Christian Dupuis, Etienne Steurbaut and Jorinde Sprong who collected the studied samples on the Tunisian outcrop. The Fund for Scientific Research Flanders (FWO-Vlaanderen) and the K.U. Leuven Research Fund are thanked for the financial support of this project. Julien Cilis of the Royal Belgian Institute of Natural Sciences is thanked for the beautiful SEM pictures. A. Lord is thanked for his discussions on earlier versions of the manuscript. The comments made by E. Kempf and an anonymous reviewer greatly improved the manuscript.

\section{Manuscript received 12 December 2005 Manuscript accepted 23 January 2007}

\section{REFERENCES}

Bassiouni, M.E.A.A. \& Luger, P. 1990. Maastrichtian to early Eocene ostracoda from southern Egypt. Palaeontology, palaeoecology, palaeobiogeography and biostratigraphy. Berliner geowissenschaftliche Abhandlungen, Reihe A, 120: 755-928.

Berggren, W.A., Aubry, M.-P., van Fossen, M., Kent, D.V., Norris, R.D. \& Quillevere, F. 2000. Integrated Paleocene calcareous plankton magnetobiochronology and stable isotope stratigraphy: DSDP Site 384 (NW Atlantic Ocean). Palaeogeography, Palaeoclimatology, Palaeoecology, 159: 1-51.

Coryell, H.N., Sample, C.H. \& Jennings, P.H. 1935. Bairdoppilata, a new genus of Ostracoda, with two new species. American Museum Novitates, 777: 1-5. 
Honigstein, A., Rosenfeld, A. \& Benjamini, C. 1991. Ostracods and foraminifera from the Early-Middle Eocene of Qeren Sartaba, Jordan Valley. Journal of Micropalaeontology, 10: 95-107.

Horne, D.J., Cohen, A. \& Martens, K. 2002. Taxonomy, morphology and biology of Quaternary and living Ostracoda. In: Holmes, J.A. \& Chivas, A.R. (Eds), The Ostracoda: applications in Quaternary research. Geophysical Monograph, 131: 5-36.

Kempf, E. 1995. Index and bibliography of marine Ostracoda 1. Index A. Geologischen Universitat Koeln Sonderveroeffentlichen, 100: 1-239.

Luger, P. 2003. Paleobiogeography of late Early Cretaceous to Early Paleocene marine Ostracoda in Arabia and North to Equatorial Africa. Palaeogeography, Palaeoclimatology, Palaeoecology, 196: 319-342.

Malz, H. 1988. The Bairdia dynasty: review-activities-aspects. In: Hanai, T., Ikeya, N. \& Ishizaki, K. (Eds), Evolutionary biology of Ostracoda, its fundamentals and applications. Elsevier, Tokyo, 75-80.

Martini, E. 1971. Standard Tertiary and Quaternary calcareous pale- oceanographic evolution of the Tethyan realm during nannoplankton zonation. In: Farinacci, A. (Ed.), Proceedings of the 2nd Planktonic Conference, Rome, 1970. Tecnoscienza, Rome, 739-785.

Morsi, A.-M.M. \& Speijer, R. 2003. High-resolution Ostracode records of the Paleocene/Eocene transition in the south eastern desert of Egypt - Taxonomy, biostratigraphy, paleoecology and paleobiogeography. Senckenbergiana lethaea, 83: 61-93.

Tanaka, G. 2005. Morphological design and fossil record of the podocopid ostracod naupliar eye. Hydrobiologia, 538: 231-242.

Van Itterbeeck, J., Sprong, J., Dupuis, C., Speijer, R.P. \& Steurbaut, E. 2007. Danian/Selandian boundary stratigraphy, paleoenvironment and Ostracoda from Sidi Nasseur, Tunisia. Marine Micropaleontology, 62: 211-234.

Varol, O. 1989. Paleocene calcareous nannofossil biostratigraphy. In: Crux, J.A. \& van Heck, S.E. (Eds), Nannofossils and their applications. Ellis Horwood Ltd, Chichester, 267-310. 